\title{
COVID-19, coagulopathy and venous thromboembolism: more questions than answers
}

\author{
Marco Marietta $^{1}$ (1) $\cdot$ Valeria Coluccio $^{1} \cdot$ Mario Luppi $^{1,2}$
}

Received: 7 June 2020 / Accepted: 2 July 2020 / Published online: 11 July 2020

(c) Società Italiana di Medicina Interna (SIMI) 2020

\begin{abstract}
The acute respiratory illnesses caused by severe acquired respiratory syndrome corona Virus-2 (SARS-CoV-2) is a global health emergency, involving more than 8.6 million people worldwide with more than 450,000 deaths. Among the clinical manifestations of COVID-19, the disease that results from SARS-CoV-2 infection in humans, a prominent feature is a pro-thrombotic derangement of the hemostatic system, possibly representing a peculiar clinicopathologic manifestation of viral sepsis. The severity of the derangement of coagulation parameters in COVID-19 patients has been associated with a poor prognosis, and the use of low molecular weight heparin (LMWH) at doses registered for prevention of venous thromboembolism (VTE) has been endorsed by the World Health Organization and by Several Scientific societies. However, some relevant issues on the relationships between COVID-19, coagulopathy and VTE have yet to be fully elucidated. This review is particularly focused on four clinical questions: What is the incidence of VTE in COVID-19 patients? How do we frame the COVID-19 associated coagulopathy? Which role, if any, do antiphospolipid antibodies have? How do we tackle COVID-19 coagulopathy? In the complex scenario of an overwhelming pandemic, most everyday clinical decisions have to be taken without delay, although not yet supported by a sound scientific evidence. This review discusses the most recent findings of basic and clinical research about the COVID-associated coagulopathy, to foster a more thorough knowledge of the mechanisms underlying this compelling disease.
\end{abstract}

Keywords COVID-19 · Coagulopathy · D-dimer · Unfractionated heparin · Low molecular weight heparin · Venous thromboembolism · Antiphospholipid antibodies $\cdot$ Disseminated intravascular coagulation $\cdot$ Sepsis-induced coagulopathy

\section{Introduction}

In December 2019, a cluster of acute respiratory illnesses caused by severe acquired respiratory syndrome corona virus-2 (SARS-CoV-2) virus occurred in Wuhan, Hubei Province, China. The disease has rapidly spread from Wuhan to many other countries, soon becoming a global health emergency. Indeed, at the time of this writing, more than 8.6 million cases of COVID19 have been reported worldwide with more than 450,000 deaths [1].

Marco Marietta

marco.marietta@unimore.it

1 Hematology Unit, Azienda Ospepdaliero-Universitaria, Via del Pozzo 71, 41124 Modena, Italy

2 Department of Medical and Surgical Sciences, Section of Hematology, University of Modena and Reggio Emilia, Modena, Italy
Although most patients have mild manifestations and good prognosis after infection, some of them develop severe symptoms and die from multiple organ complications [2-4]. The pathogenesis of COVID-19, the disease that results from SARS-CoV-2 infection in humans, remains unclear, but it is very likely that the most severe manifestations of this disease may be linked to host-pathogen interaction immune mechanisms [5, 6]. In critically ill COVID-19 patients, indeed, massive cytokine storms (including IL- 6 , TNF- $\alpha$, and other inflammatory biomarkers), as well as increments of circulating neutrophils and monocyte activation, are typically observed together with low $\mathrm{T}$ lymphocyte counts and functional exhaustion of effector $\mathrm{T}$ cell responses [5, 6]. Such ineffective and detrimental expansions of innate/ humoral responses, alongside $\mathrm{T}$ cell suppression, are reminiscent of classical features of sepsis, which is currently defined as a life-threatening organ dysfunction induced by dysregulated host response to infection, being characterized not only by systemic inflammatory response syndrome 
(SIRS) with related endothelial and organ damage, but also by impairment of adaptive $\mathrm{T}$ cell immunity $[5,6]$. Moreover, the derangement of the hemostatic system observed in end-stage COVID-19 could well fit with the idea that severe COVID-19 possibly represents a peculiar clinicopathologic form of viral sepsis, displaying a prominent prothrombotic feature instead of the hemorrhagic one observed in other viral diseases, such as Lassa, Marburg and Ebola hemorrhagic fevers [7].

From a clinical perspective, the extent of the derangement of coagulation parameters in patients affected by severe COVID-19 pneumonia has been found to be associated with a poor prognosis $[8,9]$. In these patients, low molecular weight heparin (LMWH) or unfractionated heparin (UFH) at doses registered for prevention of venous thromboembolism (VTE) seemed to be associated with a lower risk of death [10] and is currently recommended by the World Health Organization [11] and by several scientific societies [12-18] (Table 1).

However, some relevant issues on the relationships between COVID-19, coagulopathy and VTE have yet to be fully elucidated.

\section{What is the incidence of VTE in COVID-19 patients?}

Data on this issue are puzzling, as the reported incidence of VTE in COVID-19 patients ranges from $0 \%$ to about $8 \%$ in general wards [19-22], and from 16 to $35 \%$ in the ICU setting, often despite adequate LMWH prophylaxis [21-28].

An even higher rate of VTE, up to 58\%, has been reported in consecutive autopsies performed in COVID-19 patients in whom VTE was not suspected before death [29] (Table 2).

Several reasons may account for this discrepancy: just a few studies systematically screened patients for VTE, and imaging in suspected cases is challenging in the setting of a striking pandemic, with overcrowded hospital wards, given the risk of transmitting infection to other patients or health-care workers and the technical problems in performing investigation for pulmonary embolism (PE) in critically ill patients in prone position.

On this ground, it is conceivable that a non-negligible portion of PE episodes remains undiagnosed, because of these technical constraints. However, deep vein thrombosis (DVT) is rarely found in these patients [24], raising the question whether the occlusions observed in the pulmonary vascular bed of COVID-19 patients result from embolization of a DVT or from a localized thrombotic microangiopathy [19].

The question is not trivial, as the pathophysiological mechanism triggering the pulmonary vascular disease in COVID-19 could impact on the treatment.
Indeed, whereas high doses of UFH or LMWH are the mainstay of treatment in case of established pulmonary embolism from peripheral vein thrombosis, the same treatment would be ineffective, or even dangerous because of the bleeding risk, in the hypothesis that a thrombotic microangiopathy would be mainly responsible for the pulmonary vascular occlusion observed in COVID-19 patients in the absence of a proven DVT [19].

On these grounds, a better knowledge of the pathogenesis of COVID-19 coagulopathy is urgently needed to provide more precisely targeted treatments to this disease.

\section{How do we frame the COVID-19-associated coagulopathy, that is, DIC, SIC, CAC or PIC?}

Despite a rapidly growing amount of literature on this topic [7, 30-35], the pathophysiological mechanisms underlying the derangement of the hemostatic system induced by SARS-Cov2 have not been fully elucidated yet. Indeed, no evidence of an intrinsic procoagulant effect exerted by the SARS-CoV-2 virus is so far available. Therefore, the most reasonable hypothesis is that the virus activates the coagulation cascade by eliciting a large-scale inflammatory response, similar to that observed in other forms of sepsis. Several studies have already demonstrated the tight interconnection between thrombosis and inflammation, two processes mutually reinforcing each other [36, 37]. Both coagulation factors and platelets are directly implicated in the modulation of the host immune response, displaying proinflammatory functions independent of their hemostatic effects [38-40]. Moreover, the cytokines storm stimulates the expression of tissue factor on monocytes/macrophages and vascular endothelial cells, on whose surfaces the coagulation cascade is initiated. The thrombus formation at the microvascular level contributes to tissue ischemia and organ dysfunction [41].

A remarkable inflammatory response can be observed in COVID-19 patients, attested by a significant increase in fibrinogen, C-reactive protein (CRP), erythrocyte sedimentation rate (ESR), interleukin-6 (IL-6) and ferritin levels [42, 43]. Moreover, the increase of IL-6 levels has been found to correlate with that of fibrinogen, confirming the link between inflammation and procoagulant changes [44].

The hypercoagulable state of COVID-19 patients has been assessed mainly by viscoelastic methods [44-46] or by an increase in D-dimer levels, whose extent correlates with the risk of death $[8,47,48]$. This finding is not surprising, as increased D-dimer levels have already been demonstrated to be associated with a poorer outcome in other cohorts of septic patients [49].

However, the exact role of D-Dimer test in the context of COVID-19 coagulopathy deserves some further comments. 
Table 1 Main recommendations endorsed by International institutions or scientific societies on antithrombotic therapies in COVID-19

\section{Institution [ref]}

WHO [11]

ISTH [12]

SISET [13] (1)

Swiss Society of Hematology [14]

Prevention and Treatment of VTE associated with COVID-19 Infection Consensus Statement Group [15]
VTE prophylaxis in all hospitalized pts.

VTE prophylaxis after hospital discharge

VTE prophylaxis in all hospitalized pts.

ICU pts.

VTE prophylaxis in severe or critically ill pts.

VTE prophylaxis in mild and moderate pts.

VTE prophylaxis after hospital discharge

VTE treatment

VTE prophylaxis in all hospitalized pts.

VTE prophylaxis after hospital discharge
Recommendation

Recommended with LMWH [preferred] OD or UFH 5000 IU sc BID or TID in adolescents and adults without contraindications

Recommended with LMWH at prophylactic dose unless contraindicated (i.e., active bleeding, plt $<25 \times 10^{9} / L$; monitoring advised in severe renal impairment; abnormal PT or APTT is not a contraindication)

Strongly recommended with LMWH, UFH, or fondaparinux at doses indicated for VTE prophylaxis

Intermediate-dose LMWH (i.e., enoxaparin 4,000 IU BID) can be considered on an individual basis in patients with multiple risk factors for VTE (i.e., BMI > 30, previous VTE, active cancer, etc.).

Therapeutic doses of UFH or LMWH not supported by evidence outside of proven VTE

Suggested at home for 7-14 days after hospital discharge or in the pre-hospital phase, in case of pre-existing or persisting VTE risk factors

Recommended according to a risk stratification score, unless contraindicated, with LMWH if $\mathrm{CrCl}>30 \mathrm{ml} / \mathrm{min}$ according to the prescribing information; consider an increased dose in overweight patients ( $>100 \mathrm{~kg}$ ). If $\mathrm{CrCl}<30 \mathrm{ml} / \mathrm{min}$, UFH SC BID or TID or IV

Intermediate or therapeutic dosing of LMWH or UHF should be considered, according to the bleeding risk, in pts. with a large increase in D-dimers, severe inflammation, or signs of hepatic or renal dysfunction or imminent respiratory failure

Strongly recommended with LMWH in pts. at low or moderate risk of bleeding and with no contraindication

Recommended with LMWH in pts. assessed to have a high or moderate risk of VTE (PADUA or IMPROVE RAM), in the absence of contraindication

Consider prolonged outpatient VTE prophylaxis with LMWH in pts with persistent risk factors for VTE

Curative anticoagulant parenteral treatment with LMWH recommended in pts. suspected for VTE, in absence of contraindication

Recommended with LMWH or fondaparinux unless the risk of bleeding is judged to exceed the risk of thrombosis

Consider extended thromboprophylaxis after discharge using a regulatory-approved regimen (DOAC up to 40 days) 
Table 1 (continued)

\begin{tabular}{|c|c|c|}
\hline Institution [ref] & Setting & Recommendation \\
\hline \multirow[t]{3}{*}{$\begin{array}{l}\text { Anticoagulation Forum } \\
{[17]}\end{array}$} & $\begin{array}{l}\text { VTE prophylaxis in non-critically ill hospital- } \\
\text { ized pts. }\end{array}$ & $\begin{array}{l}\text { Recommended with LMWH standard doses, } \\
\text { regardless of VTE risk assessment score }\end{array}$ \\
\hline & VTE prophylaxis in ICU pts. & $\begin{array}{l}\text { Recommended with increased doses of heparin } \\
\text { (e.g., enoxaparin } 40 \mathrm{mg} \text { SC BID, enoxaparin } \\
0.5 \mathrm{mg} / \mathrm{kg} \text { SC BID, UFH } 7500 \text { IU SC TID or } \\
\text { low-intensity IV }\end{array}$ \\
\hline & VTE prophylaxis after discharge & $\begin{array}{l}\text { Not routinely recommended; consider on a } \\
\text { case-by-case basis }\end{array}$ \\
\hline \multirow[t]{3}{*}{ CHEST Guidelines [18] } & $\begin{array}{l}\text { VTE prophylaxis in acutely ill hospitalized } \\
\text { pts. }\end{array}$ & $\begin{array}{l}\text { Recommended with LMWH or fondaparinux at } \\
\text { standard doses over intermediate or full treat- } \\
\text { ment dosing or over DOAC }\end{array}$ \\
\hline & $\begin{array}{l}\text { VTE prophylaxis in critically ill hospitalized } \\
\text { pts. }\end{array}$ & $\begin{array}{l}\text { Recommended with LMWH of UFH over } \\
\text { fondaparinux or DOAC } \\
\text { Suggested current standard dose over interme- } \\
\text { diate or full treatment dosing }\end{array}$ \\
\hline & VTE prophylaxis after hospital discharge & $\begin{array}{l}\text { Recommended inpatients prophylaxis only } \\
\text { over inpatient plus extended prophylaxis after } \\
\text { hospital discharge }\end{array}$ \\
\hline
\end{tabular}

WHO World Health Organization, VTE venous thromboembolism, $O D$ once daily, $S C$ subcutaneously, $B I D$ twice daily, $T I D$ three times daily, $I V$ intravenously, ISTH International Society on Thrombosis and Hemostasis, pts patients, SISET Italian Society on Thrombosis and Hemostasis, $L M W H$ low molecular weight heparin, $U F H$ unfractionated heparin, $\mathrm{CrCl}$ Creatinine clearance, $P T$ prothrombin time, $A P T T$ activated partial thromboplastin time, $C r C L$ creatinine clearance, $I C U$ intensive care unit, $A S H$ American Society of Hematology, $D O A C$ direct oral anticoagulants

Table 2 Incidence of venous and arterial thromboembolism in hospitalized COVID-19 patients

\begin{tabular}{|c|c|c|c|}
\hline Author [ref] & Setting & $\begin{array}{l}\text { Generalized } \\
\text { VTE screening }\end{array}$ & VTE incidence \\
\hline Cattaneo [19] & $64 \mathrm{GW}$ pts on LMWH prophylaxis & yes & $0 \% \mathrm{DVT}$ \\
\hline Zhang [20] & 143 GW pts. (37\% on LMWH prophylaxis) & yes & $\begin{array}{l}16 \% \text { proximal DVT, } 30 \% \text { distal DVT (one ward) } \\
8.8 \% \text { DVT (all the hospital) }\end{array}$ \\
\hline Lodigiani [21] & $\begin{array}{l}314 \mathrm{GW} \text { pts ( } 75 \% \text { on LMWH prophylaxis) } \\
48 \text { ICU pts ( } 100 \% \text { on LMWH prophylaxis) }\end{array}$ & yes & $\begin{array}{l}\text { GW: PE } 2.5 \%, 1 \% \text { DVT (including UEDVT), 1.9\% } \\
\text { stroke } \\
\text { ICU: PE } 4.2 \%, 4.1 \% \text { isolated DVT (including } \\
\text { UEDVT), } 6.3 \% \text { stroke }\end{array}$ \\
\hline Middeldorp [22] & $\begin{array}{l}123 \mathrm{GW} \text { pts (standard LMWH prophylaxis) } \\
75 \text { ICU pts (doubled LMWH prophylaxis) }\end{array}$ & Yes $(28 \% \mathrm{GW})$ & $\begin{array}{l}\text { GW: PE } 6.6 \%, 13 \% \text { DVT (including UEDVT) } \\
\text { ICU: PE } 15 \%, 32 \% \text { DVT (including UEDVT) }\end{array}$ \\
\hline Thomas [23] & 63 ICU pts (standard LMWH prophylaxis) & no & $8 \%$ PE, $1.5 \%$ DVT (including UEDVT) \\
\hline Klok [24] & 184 ICU pts on LMWH prophylaxis & no & $\begin{array}{l}\text { 35\% PE, } 1.6 \% \text { DVT (including UEDVT) } \\
\text { 3.8\% ATE }\end{array}$ \\
\hline Poissy [25] & 107 ICU pts (100\% on VTE prophylaxis) & no & $20.6 \% \mathrm{PE}$ \\
\hline Cui [26] & $81 \mathrm{ICU}$ pts NOT on LMWH prophylaxis & yes & $25 \%$ DVT \\
\hline Llitjos [27] & $\begin{array}{l}26 \text { ICU pts } \\
\text { (31\% LMWH prophylactic, } 69 \% \text { therapeutic) }\end{array}$ & yes & $\begin{array}{l}23 \% \mathrm{PE} \\
\text { VTE significantly higher in pts. on prophylactic vs } \\
\text { therapeutic anticoagulation ( } 100 \% \text { vs. } 56 \%)\end{array}$ \\
\hline Helms [28] & $\begin{array}{l}150 \text { ICU pts } \\
\text { (70\% LMWH prophylactic, 30\% therapeutic) }\end{array}$ & no & $\begin{array}{l}16.7 \% \mathrm{PE} \\
2.6 \% \mathrm{ATE}\end{array}$ \\
\hline Whichmann [29] & $\begin{array}{l}12 \text { consecutive AUTOPSIES on COVID-19-positive } \\
\text { pts }\end{array}$ & - & $\begin{array}{l}\text { Unsuspected DVT in } 7 \text { of } 12 \text { patients }(58 \%) \\
\text { PE direct cause of death in } 4 \text { patients }\end{array}$ \\
\hline
\end{tabular}

$G W$ general ward; pts: patients, $L M W H$ low molecular weight heparin, $D V T$ deep vein thrombosis, $I C U$ intensive care Unit, $U E D V T$ upper extremity deep vein thrombosis, VTE venous thromboembolism, ATE arterial thromboembolic events, PE pulmonary embolism 
A recent review of nearly 20 papers reporting original data on D-dimer levels in COVID-19 showed some relevant bias, as most publications neither identified whether D-dimer values were reported as D-dimer units (DDU) or fibrinogen equivalent units (FEU) $(\sim 2 \times$ differences), nor report on normal cutoff values [50]. These methodological flaws greatly reduce the usefulness of this parameter on a clinical decision setting.

Moreover, the reliability of D-dimer test as prognostic factor in septic patients has already been questioned by Semeraro and colleagues in a paper published before the onset of COVID-19 pandemic [51]. The The authors found that the D-dimer levels poorly correlate with the risk of death in a population of septic patients admitted to ICU. On the other hand, they showed that D-dimer corrected for thrombin and plasmin generation $\left(\mathrm{DD}_{\text {corr }}\right)$ more properly reflects the tilting of coagulation-fibrinolysis balance, displaying a high prognostic value in septic patients [51]. Notably, the authors found the highest mortality in patients with low $\mathrm{DD}_{\text {corr }}$ levels, which reflect the fibrinolytic shutdown associated with late and more severe phases of sepsis. The mechanisms behind fibrinolysis suppression are multiple and include PAI-1 elevation, TAFI activation, and release of nuclear products such as histones and DNA.

This finding warrants particular attention in the context of COVID-19 coagulopathy, as it has been reported that fibrinolysis shutdown, assessed by elevated D-dimer levels and complete failure of clot lysis at $30 \mathrm{~min}$ on thromboelastography, predicts thromboembolic events and need for hemodialysis in critically ill COVID-19 patients [52]. Of note, in this population of 44 COVID-19 admitted to ICU, the median ISTH disseminated intravascular coagulation (DIC) score was 0 (0-2), with no patients having a score higher than 4 [52].

Consistent with this finding, other reports showed that COVID-19 patients do not typically develop overt systemic DIC, unless in the late stages of the disease, as demonstrated by the consistent observation that platelet count and fibrinogen concentration are not significantly reduced in these subjects, despite a marked increase in D-dimer concentrations $[7,8]$.

Moreover, only $21.6 \%$ of subjects in a cohort of critically ill COVID-19 patients have been found to meet the criteria for an infection-induced organ dysfunction and coagulopathy according to the sepsis-induced coagulopathy (SIC) score of the International Society on Thrombosis and Haemostasis $[7,53]$.

These findings suggest that the linear progression from SIC to DIC usually seen in septic patients does not necessarily occur in the process of SARS-Cov2 infection, which seems to be rather associated with a peculiar form of coagulopathy, termed by some authors as "COVID-19-associated coagulopathy" (CAC) [54]. CAC displays clinical and laboratory features distinct from either DIC or SIC, such as the lack of consumption of platelets and coagulation factors, first of all fibrinogen, the very low incidence of bleeding, and the main involvement of the pulmonary microcirculation, determining a localized microangiopathy, named by other authors as pulmonary intravascular coagulopathy (PIC) [55]. (Table 4).

This peculiar involvement of pulmonary microvascular bed during the course of SARS-CoV2 infection fits well with the reported high rate of acute respiratory distress syndrome (ARDS) in COVID-19 patients (about $40 \%$ of cases) [9]. Of note, ARDS itself has been identified as a hemostatic disease occurring as a result of endotheliopathy in critically ill patients. Generalized endotheliopathy in turn activates in a vicious circle the inflammatory and microthrombotic pathway, which promotes consumptive thrombocytopenia, TTP-like syndrome, and hypoxic multi-organ failure [56].

How do we gather these puzzling data on a unified clinicopathological picture, helpful to improve the management of CAC?

1. Although the mechanism underlying $\mathrm{CAC}$ has not been fully elucidated, it is conceivable that the major role in its development is played by the activation of the thromboinflammation pathway induced by a "cytokines storm" elicited by SARS-CoV2 infection.

2. As in other forms of sepsis, endothelial dysfunction leading to widespread microthrombosis, mainly localized in the pulmonary vascular bed, is observed in COVID-19 patients. In this regard, it has been demonstrated that SARS-CoV-2 uses angiotensin-converting enzyme (ACE) 2 receptor to facilitate viral entry into target cells [56, 57]. Thye ACE2 system is a critical protective pathway against heart failure, myocardial infarction and hypertension, and against lung disease and diabetes mellitus [58]. In experimental models of lung disease, catalytically active ACE2 alleviates pulmonary injury and vascular damage and prevents pulmonary hypertension, decreases lung fibrosis and arterial remodeling, and improves right ventricular performance [58]. ACE2 is highly expressed on alveolar epithelial type II cells (AECII), which can serve as a reservoir for viral invasion, and also in endothelial cells. SARS-CoV-2 infection can induce endothelial cell injury in several organs, because of direct viral involvement, of the host inflammatory response and of the induction of apoptosis and pyroptosis $[59,60]$. COVID-19-endotheliitis could explain the systemic impaired microcirculatory function in different vascular beds and the clinical sequelae in patients affected by this disease [61].

3. Thrombotic microangiopathy, induced by an enhanced platelet-vessel wall interaction, mainly induced by the release of (ultralarge) von Willebrand factor (VWF) mul- 
timers as a result of inflammation-induced endothelial cell perturbations, is thought to be a major component of the SIC [62]. The level of (ultralarge) VWF multimers in patients with sepsis has been shown to be inversely correlated with the plasma level of ADAMTS-13, and several studies have confirmed the association between low ADAMTS-13 levels and sepsis severity. Of note, very recently Bazzan and colleagues reported significantly reduced ADAMTS-13 levels in a cohort of COVID-19 patients [63]. Moreover, they found that ADAMTS-13 levels lower than $30 \%$ were significantly associated with a higher mortality, suggesting that low ADAMTS-13 associated with high plasma VWF levels can have a role in the strong prothrombotic tendency observed in COVID-19 patients [63].
Taken together, these findings suggest that the pathogenesis of CAC, although multifactorial, is mainly localized at a microvascular level, with a late involvement of venous and arterial vessels. Such a pathophysiological picture raises some questions about the effectiveness of fully antithrombotic doses of anticoagulants to effectively tackle this disease, as later discussed.

\section{Which role, if any, do antiphospholipid antibodies have?}

Among the coagulation abnormalities found in COVID-19 patients, some reports of positivity for antiphospholipid antibodies (APL) are of particular interest [64-66] (Table 3).

However, these findings are worth discussing.

Table 3 Antiphospholipid antibodies in COVID-19 patients

\begin{tabular}{|c|c|c|}
\hline Author [ref] & Setting & Relevant issues \\
\hline Zhang [64] & $3 \mathrm{ICU}$ pts with stroke & $\begin{array}{l}\text { aCL and a } \beta \text { GPI IgA } \rightarrow \text { the significance of these tests remains controversial and their implementa- } \\
\text { tion is not recommended } \\
\text { LAC not assessed }\end{array}$ \\
\hline Harzallah [65] & 56 hospitalized pts & $\begin{array}{l}45 \% \text { LAC positive } \\
\text { aCL or a } \beta 2 \text { GPI detected in only } 5 / 50 \text { pts ( } 10 \%, 3 \text { associated to LAC) using IgG and IgM detection }\end{array}$ \\
\hline Bowles [66] & $\begin{array}{l}216 \text { hospitalized pts } \\
44 \text { with prolonged APTT }\end{array}$ & $\begin{array}{l}34 / 31(91 \%) \text { with prolonged APTT were LAC positive } \\
2 \text { VTE } \\
\text { No aCL or a } 32 \text { GPI reported }\end{array}$ \\
\hline $\begin{array}{l}\text { Abdel-Wahab } \\
\text { [69] }\end{array}$ & $\begin{array}{l}\text { Systematic review on aPL } \\
\text { in viral infections }\end{array}$ & $\begin{array}{l}\mathrm{aCL}=13-63 \% \\
\mathrm{LAC}=2 \% \\
\mathrm{a} \beta 2 \mathrm{GPI}=2-9 \% \\
\text { Statistically significant increased risk of TE observed only in pts with HCV and positive aPL }\end{array}$ \\
\hline
\end{tabular}

$I C U$ intensive care unit, $a C L$ anticardiolipin antibodies, $a \beta G P I$ anti-beta2 Glicoprotein I antibodies, LAC lupus anticoagulant, $A P T T$ activated partial thromboplastin time, VTE venous thromboembolism, $H C V$ hepatitis $\mathrm{C}$ virus, $a P L$ antiphospholipid antibodies

Table 4 Main laboratory and clinical features of DIC, SIC and CAC

\begin{tabular}{|c|c|c|c|}
\hline & OVERT DIC & SIC & $\mathrm{CAC}$ \\
\hline \multicolumn{4}{|l|}{ Laboratory features } \\
\hline Platelet count & $\downarrow \downarrow \downarrow$ & $\downarrow \downarrow$ & $\leftrightarrow$ \\
\hline APTT ratio & $\uparrow \uparrow \uparrow$ & $\uparrow$ & $\leftrightarrow$ \\
\hline PT ratio/INR & $\uparrow \uparrow \uparrow$ & $\uparrow \uparrow$ & $\leftrightarrow$ \\
\hline Fibrinogen levels & $\downarrow \downarrow \downarrow$ & $\downarrow \downarrow$ & $\uparrow \uparrow \uparrow$ \\
\hline D-dimer levels & $\uparrow \uparrow$ & $\uparrow \uparrow$ & $\uparrow \uparrow \uparrow$ \\
\hline \multicolumn{4}{|l|}{ Clinical features } \\
\hline Bleeding & Common, often serious & Sometimes present & Very rare \\
\hline Microthrombosis & $\begin{array}{l}\text { Present in initial phases, then coagula- } \\
\text { tion factors consumption prevails }\end{array}$ & Present, leading to hypoxic organ dysfunction & $\begin{array}{l}\text { Very pronounced, mainly in } \\
\text { the pulmonary microcircu- } \\
\text { lation }\end{array}$ \\
\hline Organ involvement & Multi-organ failure & $\begin{array}{l}\text { Multi-organ failure: respiratory, cardiovascular, } \\
\text { hepatic, renal }\end{array}$ & Mainly pulmonary \\
\hline
\end{tabular}

$D I C$ disseminated intravascular coagulation, SIC sepsis-induced coagulopathy, $C A C$ coronavirus-associated coagulopathy, $A P T T$ activated partial thromboplastin time 
The tests for assessing APL are slippery ones, because their results are affected by several pre-, post- and analytical factors, including methodical problems due to the heterogeneity of the autoimmune antibodies, inadequate standardization of assays, differences in local working conditions, difficulties in correct interpretation of the results, lack of large prospective evaluation studies, lack of a link between antibody potency and clinical effect [67].

Notably, only the paper from Harzallah and colleagues reported the results of lupus anticoagulant (LA), anticardiolipin (aCL) and anti-beta2 glycoprotein I (aGPI) IgG and IgM tests [65], whereas current guidelines recommend performing all three tests to diagnose antiphospholipid syndrome (APS) [68].

The same guideline recommends confirming the positivity of APL on two or more occasions, at least 12 weeks apart [68], but the results of this further control, if performed, are not reported by the authors [64-66].

Moreover, the significance of positivity for aCL and aGPI $\operatorname{IgA}$, reported by Zhang and colleagues, is controversial, and the implementation of these assays is not currently recommended [64].

We should recall that APL positivity has been frequently observed during viral infections, but the association with thrombotic phenomenon on this setting is unclear, depending on the aCL and aGPI titers, especially in hepatitis B and $\mathrm{C}$ virus infections [69]. Of note, Bowles and colleagues did not report the results of aCL and aGPI tests [66], whereas Zhang and Harzallah did not report the titers of these assays $[64,65]$.

Moreover, a recently published paper from Galeano-Valle and colleagues found only $2(8.3 \%)$ cases with ACA IgM and aGPI I IgM weakly positive in a cohort of 24 COVID-19 patients with proven VTE [70].

In conclusion, we believe that there is no convincing evidence that aPL plays a relevant role in the hypercoagulable tendency of COVID-19 patients.

Therefore, we suggest that physicians should be very careful before adopting a more aggressive antithrombotic approach in COVID-19 patients only based on aPL positivity, given the many technical aspects that reduce the usefulness of these tests in such a specific setting.

\section{How do we tackle COVID-19 coagulopathy?}

First reports from the front of Wuhan showed that the use of LMWH or UFH at prophylactic doses reduced 28-day mortality in COVID-19 patients with severe pneumonia and either an SIC score $\geq 4$ (mortality rate $40.0 \%$ vs $64.2 \%$, $p=0.029$ ), or D-dimer levels $>6$-fold the upper limit of normal (mortality rate $32.8 \%$ vs $52.4 \%, p=0.017$ ) [10].
This finding prompted clinicians to look at the "good old heparin", UFH or LMWH, as the panacea for the treatment of COVID-19, because of its already well-known anticoagulant and anti-inflammatory properties [71, 72].

Indeed, LMWH has been shown to protect glycocalyx from shedding and to display immunomodulatory properties [73]. Moreover, in vitro and in vivo experimental studies have shown that human coronaviruses utilize heparin sulfate proteoglycans for attachment to target cells [74], suggesting a potential role for heparin in the therapeutic armamentarium against COVID-19.

Fondaparinux has been also proposed as a treatment for COVID-19 [75], because of its anti-inflammatory and antiviral properties $[76,77]$. Fondaparinux can be an attractive drug in this setting, as it is not associated with heparininduced thrombocytopenia, a fearful side effect of heparin treatment reported in a non-negligible part of COVID-19 patients, which is associated with a worse prognosis [78].

It is conceivable that doses of LMWH higher than those in use for the prevention of VTE in acutely ill medical patients are able to display a more intense anti-inflammatory activity, lowering cytokines storm and improving the clinical course of the disease.

However, no good evidence is available on the efficacy and safety of high dose of LMWH in COVID-19 patients, and many issues remain to be addressed, regarding the proper timing and the proper dosages and administration schemes of anticoagulant drugs.

The issue of the safety of heparin deserves close attention, as Tang and colleagues found a non-significant trend toward a negative effect of the treatment with LMWH in patients with the less severe degree of coagulopathy, as assessed by an SIC score $<4$ or D-dimer levels $<6$-fold the upper limit of normal [10].

As recently pointed out by Landi and De Servi, one-sizefits-all strategy cannot be applied to COVID-19 patients, and an individualized approach carefully balancing thrombotic and hemorrhagic risk should guide the complex management of these patients [79].

As shown in Table 1, a puzzling discrepancy exists on the doses of heparin suggested in different clinical settings, and no evidence-based recommendations can be issued.

This lack of knowledge prompted several researchers to design clinical trials, most of which randomized, comparing efficacy and safety of different doses of UFH or LMWH (mainly prophylactic vs therapeutic) in COVID-19 patients (Table 5).

From a public health's perspective, these trials failed to recruit because of a massive drop of subjects infected by SARS-Cov2.

However, in the worst case scenario of a further outbreak of the pandemic, these already existing protocols could allow to rapidly obtain a stronger evidence about the best 


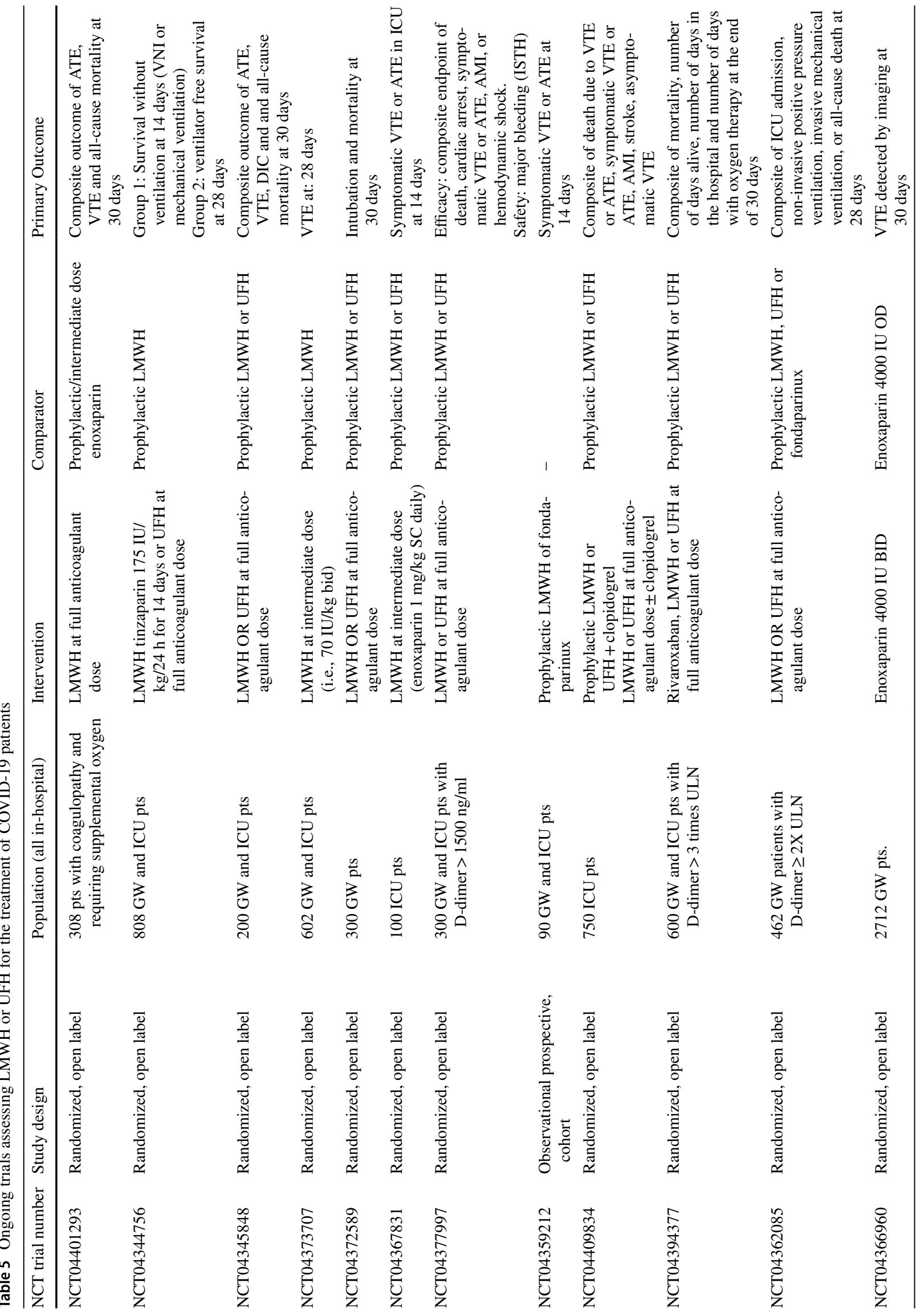




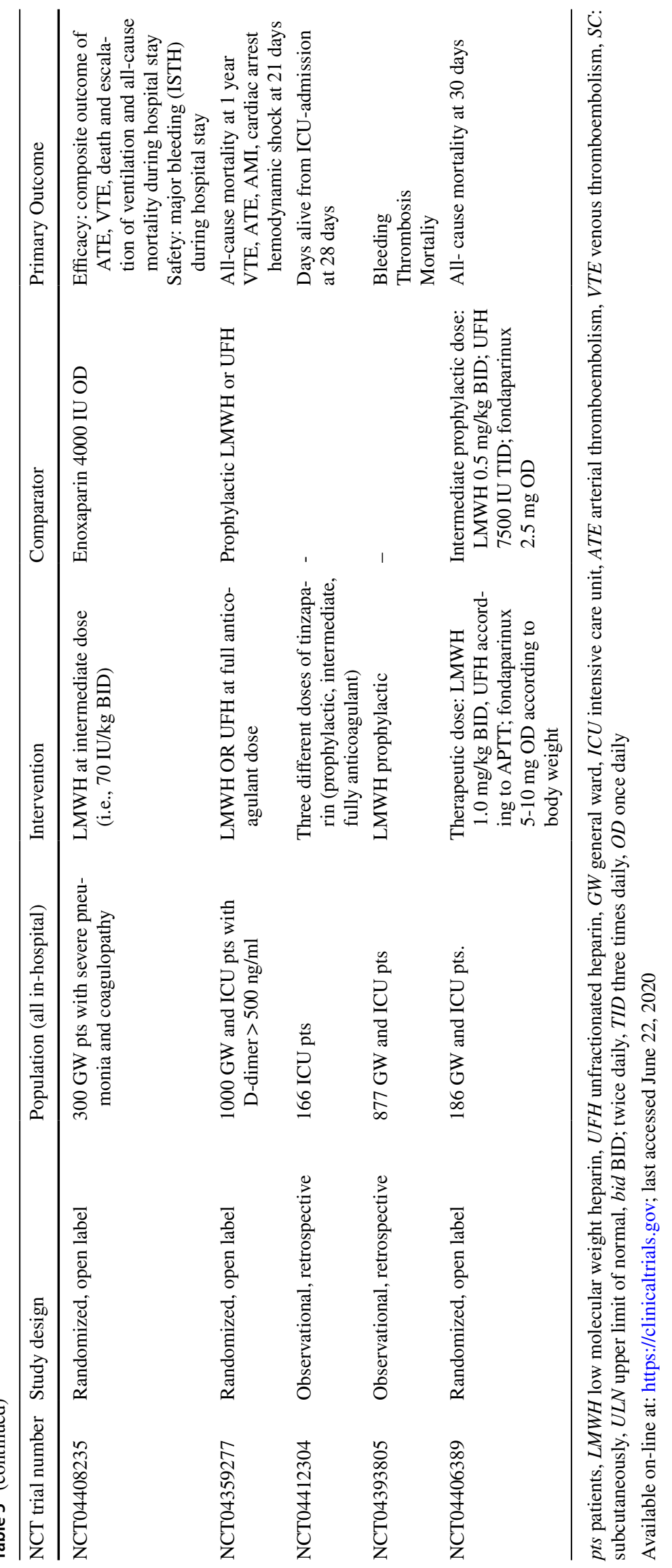


management strategies to improve the outcome of COVID19 patients.

\section{Conclusions}

The COVID-19 pandemic has disrupted many aspects of human life, forcing us to admit that medical knowledge is finite, and that the usual pathway to improve it can be too slow in the devasting scenario of an awfully fast spreading disease.

The CAC reliably illustrates this epistemological problem. The difficult journey toward a better understanding of the coagulation derangement observed in COVID-19 patients has just started, and many questions on this issue still remain unanswered.

It is therefore conceivable that physicians involved in the first-line management of COVID-19 patients are tempted to adopt conceptual shortcuts to rapidly deal with the everyday clinical problems, without waiting for an evidence which is feared to arrive too late for the patients' needs.

On this ground, the scientific community should spare no effort to ensure a faster, but always methodologically sound, process to improve medical knowledge, starting as usual from pathophysiology and cautiously moving toward a stronger evidence provided by properly designed randomized controlled trials.

Perhaps it can be a "long and winding road", but certainly it is worth traveling.

\section{Compliance with ethical standards}

Conflict of interest The Authors declare no potential conflicts of interest.

Statement of human and animal rights This article does not contain any studies with human participants or animals performed by any of the authors.

Informed consent For this type of study, formal consent is not required.

\section{References}

1. World Health Organization. Coronavirus disease (COVID-19) Situation Report-152. https://www.who.int/docs/default-sourc e/coronaviruse/situation-reports/20200620-covid-19-sitrep-152. pdf?sfvrsn=83aff8ee_4. Accessed June 21, 2020

2. Huang C, Wang Y, Li X et al (2020) Clinical features of patients infected with 2019 novel coronavirus in Wuhan, China. Lancet 395:497-506. https://doi.org/10.1016/S0140-6736(20)30183-5

3. Han H, Yang L, Liu R et al (2020) Prominent changes in blood coagulation of patients with SARS-CoV-2 infection. Clin Chem Lab Med. https://doi.org/10.1515/cclm-2020-0188.H
4. Wang D, Hu B, Hu C, Zhu F, Liu X, Zhang J, Wang B, Xiang H, Cheng Z, Xiong Y, Zhao Y, Li Y, Wang X, Peng Z (2020) Clinical characteristics of 138 hospitalized patients With 2019 novel coronavirus-infected pneumonia in Wuhan, China. JAMA 323:1061-1069. https://doi.org/10.1001/jama.2020.1585

5. Cao X (2020) COVID-19: immunopathology and its implications for therapy. Nat Rev Immunol 20(5):269-270. https://doi. org/10.1038/s41577-020-0308-3

6. Moon C (2020) Fighting COVID-19 exhausts T cells. Nat Rev Immunol. https://doi.org/10.1038/s41577-020-0304-7

7. Iba T, Levy JH, Levi M, Thachil J (2020) Coagulopathy in COVID-19. J Thromb Haemost. https://doi.org/10.1111/ jth. 14975

8. Tang N, Li D, Wang X, Sun Z (2020) Abnormal coagulation parameters are associated with poor prognosis in patients with novel coronavirus pneumonia. J Thromb Haemost 18:844-847. https://doi.org/10.1111/jth.14768

9. Wu C, Chen X, Cai Y, Xia J, Zhou X, Xu S et al (2020) Risk factors associated with acute respiratory distress syndrome and death in patients with coronavirus disease 2019 pneumonia in Wuhan, China. JAMA Intern Med 13:e200994. https://doi.org/10.1001/ jamainternmed.2020.0994

10. Tang N, Bai H, Chen X, Gong J, Li D, Sun Z (2020) Anticoagulant treatment is associated with decreased mortality in severe coronavirus disease 2019 patients with coagulopathy. J Thromb Haemost. https://doi.org/10.1111/jth.14817

11. WHO Interim guidance (2020) Clinical management of severe acute respiratory infection (SARI) when COVID-19 disease is suspected. Published 13 March 2020. https://apps.who.int/iris/ handle/10665/331446. Accessed May 52020

12. Tcachil J, Tang N, Gando S, Cattaneo M, Levi M, Clark C, Iba T (2020) ISTH interim guidance on recognition and management of coagulopathy in COVID-19. Journal Thomb Haemost. https:// doi.org/10.1111/jth.14810

13. Marietta M, Ageno W, Artoni A, De Candia E, Gresele P, Marchetti M, Marcucci R, Tripodi A (2020) COVID-19 and haemostasis: a position paper from Italian Society on Thrombosis and Haemostasis (SISET). Blood Transfus. https://doi. org/10.2450/2020.0083-20

14. Casini A, Alberio L, Angelillo-Scherrer A, Fontana P, Gerber B, Graf L et al (2020) Working party on hemostasis of the Swiss Society of Hematology. Suggestions for thromboprophylaxis and laboratory monitoring for in-hospital patients with COVID19. Swiss Med Wkly 150:w20247. https://doi.org/10.4414/ smw.2020.20247

15. Zhai Z, Li C, Chen Y, Gerotziafas G, Zhang Z, Wan J et al (2020) Prevention treatment of VTE associated with COVID-19 Infection Consensus Statement Group. Prevention and treatment of venous thromboembolism associated with coronavirus disease 2019 infection: a consensus statement before guidelines. Thromb Haemost. https://doi.org/10.1055/s-0040-1710019

16. American Society of Hematology COVID-19 Resources. COVID19 and VTE/Anticoagulation: frequently asked questions. https:// www.hematology.org/covid-19/covid-19-and-vte-anticoagulation . Accessed 06 May 2020

17. Barnes GD, Burnett A, Allen A, Blumenstein M, Clark NP, Cuker A et al (2020) Thromboembolism and anticoagulant therapy during the COVID-19 pandemic: interim clinical guidance from the anticoagulation forum. J Thromb Thrombolysis. https://doi. org/10.1007/s11239-020-02138-z

18. Moores LK, Tritschler T, Brosnahan S, Carrier M, Collen JF, Doerschug K, Holley AB, Jimenez D, LeGal G, Rali P, Wells $P$ (2020) Prevention, diagnosis and treatment of venous thromboembolism in patients with COVID-19: CHEST guideline and expert panel report. Chest S0012-3692(20):31625. https://doi. org/10.1016/j.chest.2020.05.559 
19. Cattaneo M, Bertinato EM, Birocchi S, Brizio C, Malavolta D, Manzoni M, Muscarella G, Orlandi M (2020) Pulmonary embolism or pulmonary thrombosis in COVID-19? Is the recommendation to use high-dose heparin for thromboprophylaxis justified? Thromb Haemost. https://doi.org/10.1055/s-0040-1712097

20. Zhang L, Feng X, Zhang D, Jiang C, Mei H, Wang J et al (2020) Deep vein thrombosis in hospitalized patients with coronavirus Disease 2019 (COVID-19) in Wuhan, China: prevalence, risk factors, and outcome. Circulation. https://doi.org/10.1161/CIRCU LATIONAHA.120.046702

21. Lodigiani C, Iapichino G, Carenzo L, Cecconi M, Ferrazzi P, Sebastian T, Kucher N, Studt JD, Sacco C, Alexia B, Sandri MT, Barco S, Humanitas COVID-19 Task Force (2020) Venous and arterial thromboembolic complications in COVID-19 patients admitted to an academic hospital in Milan, Italy. Thromb Res 191:9-14. https://doi.org/10.1016/j.thromres.2020.04.024

22. Middeldorp S, Coppens M, van Haaps TF, Foppen M, Vlaar AP, Müller MCA, Bouman CCS, Beenen LFM, Kootte RS, Heijmans J, Smits LP, Bonta PI, van Es N (2020) Incidence of venous thromboembolism in hospitalized patients with COVID-19. J Thromb Haemost. https://doi.org/10.1111/jth.14888

23. Thomas W, Varley J, Johnston A, Symington Robinson M, Sheares K, Lavinio A, Besseret M (2020) Thrombotic complications of patients admitted to intensive care with COVID-19 at a teaching hospital in the United Kingdom. Thromb Res. https://doi. org/10.1016/j.thromres.2020.04.028

24. Klok FA, Kruip MJHA, van der Meer NJM, Arbous MS, Gommers D, Kant KM, Kaptein FHJ, van Paassen J, Stals MAM, Huisman MV, Endeman H (2020) Confirmation of the high cumulative incidence of thrombotic complications in critically ill ICU patients with COVID-19: an updated analysis. Thromb Res. https://doi. org/10.1016/j.thromres.2020.04.041

25. Poissy J, Goutay J, Caplan M, Parmentier E, Duburcq T, Lassalle F, Jeanpierre E, Rauch A, Labreuche J, Susen S, Lille ICU Haemostasis COVID-19 group (2020) Pulmonary Embolism in COVID-19 patients: awareness of an increased prevalence. Circulation. https://doi.org/10.1161/circulationaha.120.047430

26. Cui S, Chen S, Li X, Liu S, Wang F (2020) Prevalence of venous thromboembolism in patients with severe novel coronavirus pneumonia. J Thromb Haemost. https://doi.org/10.1111/jth.14830

27. Llitjos JF, Leclerc M, Chochois C, Monsallier JM, Ramakers M, Auvray M, Merouani K (2020) High incidence of venous thromboembolic events in anticoagulated severe COVID-19 patients. $\mathrm{J}$ Thromb Haemost. https://doi.org/10.1111/jth.14869

28. Helms J, Tacquard C, Severac F, Leonard-Lorant I, Ohana M, Delabranche X et al (2020) CRICS TRIGGERSEP Group (Clinical Research in Intensive Care and Sepsis Trial Group for Global Evaluation and Research in Sepsis). High risk of thrombosis in patients with severe SARS-CoV-2 infection: a multicenter prospective cohort study. Intensive Care Med. https://doi. org/10.1007/s00134-020-06062-x

29. Wichmann D, Sperhake JP, Lütgehetmann M, Steurer S, Edler C, Heinemann A et al (2020) Autopsy findings and venous thromboembolism in patients with COVID-19: a prospective cohort study. Ann Intern Med. https://doi.org/10.7326/M20-2003

30. Violi F, Pastori D, Cangemi R, Pignatelli P, Loffredo L (2020) Hypercoagulation and antithrombotic treatment in coronavirus 2019: a new challenge. Thromb Haemost. https://doi. org/10.1055/s-0040-1710317

31. Becker RC (2020) COVID-19 update: Covid-19-associated coagulopathy. J Thromb Thrombolysis 15:1-14. https://doi.org/10.1007/ s11239-020-02134-3

32. Bikdeli B, Madhavan MV, Jimenez D, Chuich T, Dreyfus I, Driggin E, Nigoghossian Der et al (2020) COVID-19 and thrombotic or thromboembolic disease: implications for prevention, antithrombotic therapy, and follow-up. J Am Coll Cardiol. https ://doi.org/10.1016/j.jacc.2020.04.031

33. Thachil J, Agarwal S (2020) Understanding the COVID-19 coagulopathy spectrum. Anaesthesia. https://doi.org/10.1111/ anae. 15141

34. Boccia M, Aronne L, Celia B, Mazzeo G, Ceparano M, D’Agnano $\mathrm{V}$ et al (2020) COVID-19 and coagulative axis: review of emerging aspects in a novel disease. Monaldi Arch Chest Dis. https:// doi.org/10.4081/monaldi.2020.1300

35. Jackson SP, Darbousset R, Schoenwaelder SM (2019) Thromboinflammation: challenges of therapeutically targeting coagulation and other host defense mechanisms. Blood 133:906-918. https:// doi.org/10.1182/blood-2018-11-882993

36. Iba T, Levy JH (2018) Inflammation and thrombosis: roles of neutrophils, platelets and endothelial cells and their interactions in thrombus formation during sepsis. J Thromb Haemost 16:231241. https://doi.org/10.1111/jth.13911

37. Claushuis TAM, de Stoppelaar SF, Stroo I, Roelofs JJ, Ottenhoff R, van der Poll T, Van't Veer C (2017) Thrombin contributes to protective immunity in pneumonia-derived sepsis via fibrin polymerization and platelet-neutrophil interactions. J Thromb Haemost 15:744-757. https://doi.org/10.1182/blood-2017-06788067

38. Burzynski LC, Humphry M, Pyrillou K, Wiggins KA, Chan JNE, Figg N, Kitt LL et al (2019) The coagulation and immune systems are directly linked through the activation of interleukin- $1 \alpha$ by thrombin. Immunity 50(1033-1042):e6. https://doi.org/10.1016/j. immuni.2019.03.003

39. Chen J, Li X, Li L et al (2019) Coagulation factors VII, IX and X are effective antibacterial proteins against drug-resistant Gramnegative bacteria. Cell Res 29:711-724. https://doi.org/10.1038/ s41422-019-0202-3

40. Assinger A, Schrottmaier WC, Salzmann M, Rayes J (2019) Platelets in sepsis: an update on experimental models and clinical data. Front Immunol 10:1687. https://doi.org/10.3389/fimmu .2019 .01687

41. Grover SP, Mackman N (2018) Tissue factor: an essential mediator of hemostasis and trigger of thrombosis. Arterioscler Thromb Vasc Biol 38:709-725. https://doi.org/10.1161/ATVBA HA.117.309846

42. Chen G, Wu D, Guo W, Cao Y, Huang D, Wang H et al (2020) Clinical and immunologic features in severe and moderate Coronavirus Disease 2019. J Clin Invest 130:2620-2629. https://doi. org/10.1172/JCI137244

43. Colafrancesco S, Alessandri C, Conti F, Priori R (2020) COVID19 gone bad: a new character in the spectrum of the hyperferritinemic syndrome? Autoimmun Rev 19:102573. https://doi. org/10.1016/j.autrev.2020.10257

44. Ranucci M, Ballotta A, Di Dedda U, Bayshnikova E, Dei Poli M, Resta M, Falco M, Albano G, Menicanti L (2020) The procoagulant pattern of patients with COVID-19 acute respiratory distress syndrome. J Thromb Haemost. https://doi.org/10.1111/jth.14854

45. Panigada M, Bottino N, Tagliabue P, Grasselli G, Novembrino C, Chantarangkul V, Pesenti A, Peyvandi F, Tripodi A (2020) Hypercoagulability of COVID-19 patients in intensive care unit a report of thromboelastography findings and other parameters of hemostasis. J Thromb Haemost. https://doi.org/10.1111/jth.14850

46. Spiezia L, Boscolo A, Poletto F, Cerruti L, Tiberio I, Campello E, Navalesi P, Simioni P (2020) COVID-19-related severe hypercoagulability in patients admitted to intensive care unit for acute respiratory failure. Thromb Haemost. https://doi. org/10.1055/s-0040-1710018

47. Han H, Yang L, Liu R et al (2020) Prominent changes in blood coagulation of patients with SARS-CoV-2 infection. Clin Chem Lab Med. https://doi.org/10.1515/cclm-2020-0188 
48. Lippi G, Favaloro EJ (2020) D-dimer is associated with severity of coronavirus disease 2019: a pooled analysis. Thromb Haemost 120:876-878. https://doi.org/10.1055/s-0040-1709650

49. Rodelo JR, De la Rosa G, Valencia ML et al (2012) D-dimer is a significant prognostic factor in patients with suspected infection and sepsis. Am J Emerg Med 30:1991-1999. https://doi. org/10.1016/j.ajem.2012.04.033

50. Favaloro EJ, Thachil J (2020) Reporting of D-dimer data in COVID-19: some confusion and potential for misinformation. Clin Chem Lab Med. https://doi.org/10.1515/cclm-2020-0573

51. Semeraro F, Ammollo CT, Caironi P et al (2019) D-dimer corrected for thrombin and plasmin generation is a strong predictor of mortality in patients with sepsis. Blood Transfus 19:1-8. https://doi.org/10.2450/2019.0175-19

52. Wright FL, Vogler TO, Moore EE, Moore HB, Wohlauer MV, Urban S et al (2020) Fibrinolysis shutdown correlates to thromboembolic events in severe COVID-19 infection. Am Coll Surg. https://doi.org/10.1016/j.jamcollsurg.2020.05.007

53. Iba T, Levy JH, Warkentin TE, Thachil J, van der Poll T, Levi M (2019) Scientific and standardization committee on DIC, and the scientific and standardization committee on perioperative and critical care of the international society on thrombosis and haemostasis. Diagnosis and management of sepsis-induced coagulopathy and disseminated intravascular coagulation. J Thromb Haemost 17(11):1989-1994. https://doi.org/10.1111/ jth.14578

54. Connors JM (2020) Levy JH COVID-19 and its implications for thrombosis and anticoagulation. Blood. https://doi.org/10.1182/ blood.2020006000

55. Fogarty H, Townsend L, Cheallaigh CN, Bergin C, MartinLoeches I, Browne P et al (2020) COVID-19 coagulopathy in caucasian patients. Br J Haematol. https://doi.org/10.1111/ bjh.16749

56. Chang JC (2019) Acute respiratory distress syndrome as an organ phenotype of vascular microthrombotic disease: based on hemostatic theory and endothelial molecular pathogenesis. Clin Appl Thromb/Hemost 25:1-20. https://doi.org/10.1177/10760 29619887437

57. Zhang H, Penninger JM, Li Y, Zhong N, Slutsky A (2020) Angiotensin-converting enzyme 2 (ACE2) as a SARS-CoV-2 receptor: molecular mechanisms and potential therapeutic target. Intensive Care Med 46:586-590. https://doi.org/10.1007/ s00134-020-05985-9

58. Gheblawi M, Wang K, Viveiros A, Nguyen Q, Zhong JC, Turner AJ, Raizada MK, Grant MB, Oudit GY (2020) Angiotensinconverting enzyme 2: SARS-CoV-2 receptor and regulator of the renin-angiotensin system: celebrating the 20th anniversary of the discovery of ACE2. Circ Res 126:1456-1474. https://doi. org/10.1161/CIRCRESAHA.120.317015

59. Henry BM, Vikse J, Benoit S, Favaloro EJ, Lippi G (2020) Hyperinflammation and derangement of renin-angiotensinaldosterone system in COVID-19: a novel hypothesis for clinically suspected hypercoagulopathy and microvascular immunothrombosis. Clin Chim Acta 26(507):167-173. https://doi. org/10.1016/j.cca.2020.04.027

60. Albini A, Di Guardo G, McClain Noonan D, Lombardo M (2020) The SARS-CoV-2 receptor, ACE-2, is expressed on many different cell types: implications for ACE-inhibitor- and angiotensin II receptor blocker-based cardiovascular therapies. Intern Emerg Med 19:1-8. https://doi.org/10.1007/s11739-02002364-6

61. Varga Z, Flammer AJ, Steiger P, Haberecker M, Andermatt R, Zinkernagel AS, Mehra MR, Schuepbach RA, Ruschitzka F (2020) Moch endothelial cell infection and endotheliitis in COVID-19. Lancet 395:1417-1418. https://doi.org/10.1016/ S0140-6736(20)30937-5
62. Levi M, Scully M, Singer M (2018) The role of ADAMTS-13 in the coagulopathy of sepsis. J Thromb Haemost 16:646-651. https://doi.org/10.1111/jth.13953

63. Bazzan M, Montaruli B, Sciascia S et al (2020) Low ADAMTS 13 plasma levels are predictors of mortality in COVID-19 patients. Intern Emerg Med. https://doi.org/10.1007/s1173 9-020-02394-0

64. Zhang Y, Xiao M, Zhang S, Xia P, Cao W, Jiang W et al (2020) Coagulopathy and antiphospholipid antibodies in patients with Covid-19. N Engl J Med. https://doi.org/10.1056/NEJMc20075 75

65. Harzallah I, Debliquis A, Drénou B (2020) Lupus anticoagulant is frequent in patients with Covid-19. J Thromb Haemost. https ://doi.org/10.1111/jth.14867

66. Bowles L, Platton S, Yartey N, Dave M, Lee K, Hart DP, MacDonald V, Green L, Sivapalaratnam S, Pasi KJ, MacCallum P (2020) Lupus anticoagulant and abnormal coagulation tests in patients with Covid-19. N Engl J Med. https://doi.org/10.1056/ NEJMc2013656

67. Devreese KMJ (2014) Antiphospholipid antibody testing and standardization. Int J Lab Hematol 36:352-363. https://doi. org/10.1111/ijlh.12234

68. Devreese KMJ, Ortel TL, Pengo V, de Laat B (2018) Subcommittee on lupus anticoagulant/antiphospholipid antibodies. Laboratory criteria for antiphospholipid syndrome: communication from the SSC of the ISTH. J Thromb Haemost 16:809-813. https://doi.org/10.1111/jth.13976

69. Abdel-Wahab N, Talathi S, Lopez-Olivo MA, Suarez-Almazor ME (2018) Risk of developing antiphospholipid antibodies following viral infection: a systematic review and meta-analysis. Lupus 27:572-583. https://doi.org/10.1177/096120331773153 2

70. Galeano-Valle F, Oblitas CM, Ferreiro-Mazón MM, AlonsoMuñoz J, Del Toro-Cervera J, Demelo-Rodríguez P (2020) Antiphospholipid antibodies are not elevated in patients with severe COVID-19 pneumonia and venous thromboembolism. Thromb Res 192:113-115. https://doi.org/10.1016/j.throm res.2020.05.017

71. Li X, Ma X (2017) The role of heparin in sepsis: much more than just an anticoagulant. Br J Haematol 179:389-398. https ://doi.org/10.1111/bjh.14885

72. Thachil J (2020) The versatile heparin in COVID-19. J Thromb Haemost 18:1020-1022. https://doi.org/10.1111/jth.14821

73. Huang X, Han S, Liu X, Wang T, Xu H, Xia B et al (2020) Both UFH and NAH alleviate shedding of endothelial glycocalyx and coagulopathy in LPS-induced sepsis. Exp Ther Med 19:913-922. https://doi.org/10.3892/etm.2019.8285

74. Milewska A, Zarebski M, Nowak P, Stozek K, Potempa J, Pyrc K (2014) Human coronavirus NL63 utilizes heparan sulfate proteoglycans for attachment to target cells. J Virol 88:1322113230. https://doi.org/10.1128/JVI.02078-14

75. Marongiu F, Grandone E, Barcellona D (2020) Pulmonary thrombosis in 2019-nCoV pneumonia? J Thromb Haemost 18:1511-1513. https://doi.org/10.1111/jth.14818

76. Keshari RS, Silasi R, Popescu NI, Georgescu C, Chaaban H, Lupu $C$ et al (2020) Fondaparinux pentasaccharide reduces sepsis coagulopathy and promotes survival in the baboon model of Escherichia coli sepsis. J Thromb Haemost 18:180-190. https ://doi.org/10.1111/jth.14642

77. Xie Q, Spear JM, Noble AJ, Sousa DR, Meyer NL, Davulcu O et al (2017) The $2.8 \AA$ Electron Microscopy Structure of AdenoAssociated Virus-DJ Bound by a Heparinoid Pentasaccharide. Mol Ther Methods Clin Dev. 5:1-12. https://doi.org/10.1016/j. omtm.2017.02.004

78. Liu X, Zhang X, Xiao Y, Gao T, Wang G, Wang Z et al (2020) Heparin-induced thrombocytopenia is associated 
with a high risk of mortality in critical COVID-19 patients receiving heparin-involved treatment. MedRxiv. https://doi. org/10.1101/2020.04.23.20076851

79. Landi A, De Servi S (2020) The burden of thrombotic complications in critically ill patients with COVID-19: charting the uncharted. Intern Emerg Med. https://doi.org/10.1007/s1173 9-020-02393-1
Publisher's Note Springer Nature remains neutral with regard to jurisdictional claims in published maps and institutional affiliations. 